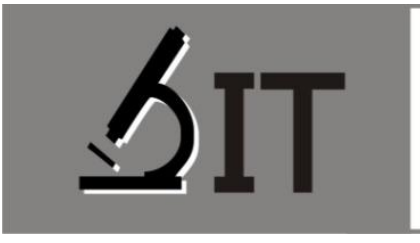

p-ISSN : 2597-8977

e-ISSN : 2597-8985

Ennar Winarti*)

Prodi Pendidikan IPA FMIPA

Universitas Negeri Makassar

Muh Tawi

Prodi Pendidikan IPA FMIPA

Universitas Negeri Makassar

Ratnawaty Mamin

Prodi Pendidikan IPA FMIPA

Universitas Negeri Makassa
JIT 4 (2) (2021) 1-11

JURNAL IPA TERPADU

http://ojs.unm.ac.id/index.php/ipaterpadu

\section{PENGARUH MODEL PEMBELAJARAN TIPE MAKE $A$ MATCH TERHADAP HASIL BELAJAR IPA PESERTA DIDIK KELAS VIII SMPN 31 BULUKUMBA (STUDI PADA MATERI
POKOK SISTEM PENCERNAAN MANUSIA)}

Abstrak: Penelitian bertujuan: (1) Menganalisis peningkatan hasil belajar IPA dibelajarkan dengan model kooperatif tipe make a match dan dengan model pembelajaran konvensional, (2) Menguji pengaruh antara hasil belajar IPA dibelajarkan dengan model pembelajaran kooperatif tipe make a match dan dibelajarkan menggunakan model pembelajaran konvensional. Penelitian ini merupakan eksperimen semu dengan desain penelitian Nonequivalent Control Group Design. Populasi adalah seluruh peserta didik kelas VIII SMPN 31 Bulukumba sekaligus sebagai sampel. Instrument penelitian berupa tes hasil belajar pilihan ganda berjumlah 25 soal. Teknik pengumpulan data penelitian adalah pemberian pretest dan posttest. Data dianalisis dengan statistik deskriptif. Hasil analisis deskriptif: (1) Rata-rata peningkatan hasil belajar IPA yang dibelajarkan dengan menggunakan model pembelajaran kooperatif tipe Make a Match dengan skor $\mathrm{N}$-Gain 0,701 dan dengan model pembelajaran konvensional dengan skor N-Gain 0,318, (2) Terdapat perbedaan hasil belajar yang dibelajarkan menggunakan model pembelajaran kooperatif tipe Make a Match lebih tinggi dengan dibelajarkan model pembelajaran konvensional. Hasil analisis inferensial menggunakan uji-t diperoleh bahwa terdapat perbedaan peningkatan hasil belajar IPA peserta didik dibelajarkan menggunakan model pembelajaran kooperatif tipe make a match. Jadi, disimpulkan bahwa pembelajaran kooperatif tipe make a match dapat meningkatkan hasil belajar peserta didik.

Kata Kunci: Make A Match, Hasil Belajar.

Abstract: This study aims to (1) analyze how high the increase in science learning outcomes who are taught with a make-match type cooperative model and with conventional learning models, (2) test the difference between science learning outcomes for students in class VI II at SMP N 31 Bulukumba who are taught with cooperative learning models of make a match type and students who are taught using conventional learning models. This research is a quasi-experimental research with Nonequivalent Control Group Design. The population were all students of class VIII 31 of SMP Negeri 31 Bulukumba as well as samples. The research instrument of learning outcomes is in the form of multiple choice. Data collection techniques were the provision of pretest and posttest. Data were analyzed with descriptive statistics. The results of the descriptive analysis concluded that: (1) The average increase in science learning outcomes for and which is taught using conventional learning models, and (2) There are differences in learning outcomes of students who are taught using the Make a Match type cooperative learning model with students who are taught using conventional learning models. So, it can be concluded that the make a match type of cooperative learning model can be used to improve student learning outcomes.
Ennarwinarti26@gmail.com 


\section{PENDAHULUAN}

Keyword: make a match, learning outcomes

Ilmu Pengetahuan Alam (IPA) merupakan suatu ilmu pengetahuan yang sangat dekat dengan alam. Dalam konsep-konsepnya selalu berhubungan dengan fakta-fakta yang nyata. Belajar IPA bukan hanya sekedar menghafalkan konsep dan prinsip saja tetapi juga memahami isi yang terkandung di dalamnya. IPA adalah ilmu pengetahuan yang bertujuan untuk menanamkan dan mengembangkan pengetahuan (kognitif), sikap (afektif), dan keterampilan (psikomotorik). Berdasarkan hal tersebut tampak bahwa hasil pembelajaran IPA sangat diharapkan tercermin dari kemampuan peserta didik dalam memahami materi IPA dan fenomena-fenomena alam yang terjadi di sekitarnya. Oleh karena itu pendidik perlu merancang pembelajaran IPA yang menarik dan berpusat pada peserta didik sehingga tujuan pembelajaran IPA dapat tercapai.

Berdasarkan observasi yang telah peneliti lakukan di SMP Negeri 31 Bulukumba, diketahui bahwa peserta didik kelas VIII di sekolah tersebut mengalami kesulitan dalam memahami materi pelajaran yang bersifat abstrak. Kegiatan pembelajaran yang berpusat pada pendidik (teacher centered) yaitu peserta didik mendengarkan penjelasan pendidik lalu mencatat hal-hal yang penting, melakukan presentasi, dan penugasan. Presentasi yang dilakukan hanya mencari sumber materi dari buku paket dan modul IPA, kemudian dalam diskusi kelompok suasana yang sangat pasif dimana hanya ada satu dua orang dari anggotanya yang lebih aktif, sedangkan anggota yang lainnya hanya mengandalkan temannya, selanjutnya pendidik akan memberikan latihan atau tugas yang pertanyaan-pertanyaan yang hampir seluruh jawabannya ada di buku paket IPA. Hal ini sering dilakukan oleh pendidik sehingga membuat peserta didik kurang memahami materi yang disampaikan. Proses pembelajaran yang dilakukan di kelas sebelumnya merupakan pembelajaran kooperatif dengan membentuk kelompok dengan jumlah peserta didik 4-5 orang, dalam hal ini anggota dari kelompok tersebut hanya 1 atau 2 orang saja yang aktif, hal ini membuat peserta didik lainnya tidak ikut berpartisipasi dalam kelompoknya. Akibatnya, peserta didik kurang merasakan secara langsung manfaat dari proses pembelajaran yang dilakukan.

Pada pembelajaran IPA, contohnya materi pokok sistem pencernaan manusia, peserta didik diharapkan mampu memahami struktur dan fungsi sistem pencernaan manusia. Dengan model pembelajaran yang diterapkan di SMP Negeri 31 Bulukumba, dimana pembelajaran hanya berpusat kepada pendidik (teacher centered), dalam hal ini proses pembelajaran masih kurang efektif untuk peserta didik memahami materi yang disampaikan.

Upaya yang dapat dilakukan untuk mengatasi permasalahan tersebut adalah memilih model pembelajaran yang tepat juga diharapkan mampu mempermudah proses pembelajaran bagi pendidik untuk mencapai tujuan pembelajaran secara optimal. Salah satu cara yang dapat digunakan oleh pendidik dalam meningkatkan hasil belajar peserta didik adalah penerapan pembelajaran kooperatif. Tujuan dari pembelajaran dasar pemilihan kooperatif itu sendiri adalah pemanfaatan kelompok kecil dalam proses pembelajaran yang memungkinkan kerja sama dalam menuntaskan permasalahan di kelas. Kooperatif menurut (Slavin, 2009), merupakan salah satu model pembelajaran dengan membentuk peserta didik belajar dalam kelompok-kelompok kecil. Pada implementasi pembelajaran IPA, calon peneliti menerapkan tipe Make A Match. Metode ini dikembangkan oleh Lorna Curran (1994) dalam (Fatimatuzzahro, Subiki, \& Wahyuni, 2015). Salah satu keunggulan teknik ini adalah peserta didik mencari pasangan sambil belajar mengenai suatu konsep atau topik, dalam suasana yang menyenangkan. Penerapan metode ini dimulai dengan teknik, yaitu peserta didik disuruh mencari pasangan kartu yang merupakan jawaban/soal sebelum batas waktunya, peserta didik yang dapat mencocokkan kartunya diberi poin.

Sejalan dengan penelitian yang dilakukan oleh (Fatimatuzzahro, Subiki, \& Wahyuni, 2015), hasil penelitian yang dilakukan menunjukkan bahwa ada perbedaan yang signifikan antara hasil belajar IPA peserta didik menggunakan model cooperative learning tipe make a match dengan model yang biasa digunakan di SMP. Rekapitulasi nilai hasil belajar IPA peserta didik menunjukkan 
bahwa peserta didik mendapatkan pelajaran dengan menggunakan model cooperative tipe make a match lebih tinggi dibanding dengan menggunakan model yang biasa digunakan. Sehingga model cooperative learning tipe make a match lebih baik digunakan.

Cooperative Learning merupakan kegiatan belajar peserta didik yang dilakukan dengan cara berkelompok. Model pembelajaran kelompok adalah rangkaian kegiatan belajar yang dilakukan oleh peserta didik dalam kelompok-kelompok tertentu untuk mencapai tujuan pembelajaran yang telah dirumuskan Sanjaya dalam, (Rusman, 2016).

Menurut (Mikran, Pasaribu, \& Darmadi, 2013), metode make a match merupakan metode belajar mengajar mencari pasangan dimana peserta didik mencari pasangan sambil belajar mengenai suatu konsep atau topik dalam suasana yang menyenangkan. Jumlah peserta didik dalam satu kelompok tidak boleh terlalu besar, yang terdiri dari 2 orang atau lebih. Hal ini dimaksud agar proses kerjasama antar peserta didik berjalan efektif, sehingga memungkinkan semua peserta didik terlibat secara aktif dalam pembelajaran untuk membahas dan memecahkan masalah. Dalam kelompok kecil itu peserta didik belajar dan bekerjasama sampai pada pengalaman belajar yang maksimal, baik yang bersifat pengalaman individual maupun kolektif sebagai cerminan adanya prinsip-prinsip keaktifan peserta didik dalam pembelajaran.

Kurniasih dan Sani (2017) menguraikan langkah-langkah pembelajaran kooperatif tipe make a match berdasarkan dengan model yang dikembangkan oleh Lorna Curran (1994) sebagai berikut:

1. Pendidik menyiapkan beberapa kartu yang berisi konsep atau topik yang cocok untuk sesi review, satu bagian kartu soal dan bagian lainnya kartu jawaban.

2. Setiap peserta didik mendapatkan sebuah kartu yang bertuliskan soal atau jawaban.

3. Tiap peserta didik memikirkan jawaban atau soal dari kartu yang dipegang.

4. Setiap peserta didik mencari pasangan kartu yang cocok dengan kartunya.

5. Setiap peserta didik yang dapat mencocokan kartunya sebelum batas waktu diberi poin.

6. Jika peserta didik tidak dapat mencocokkan kartunya dengan kartu temannya (tidak dapat menemukan kartu soal atau kartu jawaban) akan mendapat hukuman, yang telah disepakati bersama.

7. Setelah satu babak, kartu dikocok lagi agar setiap peserta didik mendapat kartu yang berbeda dari sebelumnya, demikian seterusnya.

8. Peserta didik juga bisa bergabung dengan 2 atau 3 peserta didik lainnya yang memegang kartu yang cocok.

9. Pendidik bersama-sama dengan peserta didik membuat kesimpulan terhadap materi pelajaran.

Hasil belajar adalah kemampuan-kemampuan yang dimiliki peserta didik setelah menerima pengalaman belajar. Hasil belajar merupakan suatu penilaian akhir dari proses dan pengenalan yang telah dilakukan berulang-ulang dan akan tersimpan dalam jangka waktu lama. Hasil belajar turut serta dalam membentuk pribadi individu yang selalu ingin mencapai hasil yang lebih baik lagi sehingga akan merubah cara berpikir serta perilaku kerja yang lebih baik. Hasil belajar digunakan oleh pendidik untuk dijadikan ukuran atau kriteria dalam mencapai suatu tujuan pembelajaran (Iwan \& Lestari, 2015).

Lingkup penilaian hasil belajar oleh pendidik mencakup kompetensi sikap (spiritual dan sosial), pengetahuan dan keterampilan (Permendikbud, 2014). Berdasarkan hasil revisi taksonomi Bloom, masing-masing ranah tersebut memiliki beberapa aspek, yaitu:

1) Sikap (spiritual dan sosial)

Ranah sikap dalam kurikulum 2013 menggunakan olahan Krathwhol, dimana pembentukan sikap peserta didik ditata secara hierarki mulai dari menerima (accepting), merespon/menanggapi (responding), menghargai (valuing), menghayati (organizing/internalizing) dan mengamalkan (characterizing/actualizing) (Permendikbud, 2014). 
Menurut (Permendikbud, 2014), ranah pengetahuan pada kurikulum 2013 menggunakan taksonomi Bloom olahan Anderson, dimana perkembangan kemampuan mental intelektual peserta didik dimulai dari: mengingat (remember); memahami (understand); menerapkan (apply); menganalisis (analiyze); mengevaluasi (evaluate)

3) Ranah Keterampilan

Menurut (Permendikbud, 2014), ranah keterampilan pada kurikulum 2013 yang mengarah pada pembentukan keterampilan abstrak menggunakan gradasi dari dyers yang ditata sebagai berikut: (1) mengamati (Observing); (2) menanya (questioning); (3) mengumpulkan informasi/ mencoba (experimenting); (4) menalar/ mengasosiasi (associating); dan (5) mengkomunikasikan (communicating).

Berdasarkan uraian di atas, maka tujuan penelitian ini sebagai berikut:

1. Menganalisis peningkatan hasil belajar IPA peserta didik yang dibelajarkan dengan model kooperatif tipe make a match.

2. Menganalisis peningkatan hasil belajar IPA peserta didik yang dibelajarkan dengan model pembelajaran konvensional,

3. Menguji pengaruh antara hasil belajar IPA peserta didik yang dibelajarkan dengan model pembelajaran kooperatif tipe make a match dan yang dibelajarkan menggunakan model pembelajaran konvensional.

\section{METODE}

Jenis penelitian yang digunakan adalah eksperimen semu (quasi eksperiment) dengan desain penelitian nonequivalent control group design. Penelitian dilaksanakan pada Semester Ganjil Tahun Ajaran 2019/2020 di SMP Negeri 31 Bulukumba.

Pengambilan sampel dilakukan dengan teknik sampling jenuh, yaitu teknik penentuan sampel bila semua anggota populasi digunakan sebagai sampel. Populasi dalam penelitian ini adalah seluruh peserta didik kelas VIII SMP Negeri 31 Bulukumba dengan jumlah total peserta didik sebanyak 51 orang. Adapun sampel penelitiannya adalah kelas VIII B sebagai kelompok kontrol dengan jumlah peserta didik sebanyak 25 orang dan kelas VIII A sebagai kelompok eksperimen dengan jumlah peserta didik sebanyak 26 orang. Variabel yang diselidiki dalam penelitian ini adalah model pembelajaran kooperatif tipe make a match dan model konvensional dengan hasil belajar.

Data hasil belajar peserta didik diperoleh melalui pemberian tes hasil belajar berupa tes tertulis pretest (sebelum diberikan perlakuan) dan posttest dalam bentuk pilihan ganda sebanyak 25 item. Data yang diperoleh dari sampel penelitian ini berupa data kuantitatif skor hasil belajar peserta didik yang kemudian diolah dengan statistik deskriptif dan statistik inferensial. Statistik deskriptif digunakan untuk mendeskripsikan tingkat hasil belajar yang diperoleh peserta didik. Hal ini dimaksudkan untuk mengetahui skor rata-rata, standar deviasi, variansi, skor maksimum, skor minimum dan distribusi frekuensi. Perhitungan skor pada soal hasil belajar dilakukan berdasarkan pedoman Tabel 1. 
Tabel 1. Perhitungan Skor pada Soal Berbeda Bobot

\begin{tabular}{lc}
\hline \multicolumn{1}{c}{ Jenjang Domain Kognitif } & Bobot (b) \\
\hline Pengetahuan (C1) & 1 \\
Pemahaman (C2) & 2 \\
Aplikasi (C3) & \multicolumn{2}{c}{3} \\
Analisis (C4) & \multicolumn{2}{c}{4} \\
Sintesis (C5) & 5 \\
Evaluasi (C6) & 6 \\
\hline & (Arifin, 2016)
\end{tabular}

Skor hasil belajar kemudian dianalisis dengan N-gain untuk melihat peningkatan dari pretest dan posttest. $\mathrm{N}$-gain adalah perbandingan skor posttest dengan selisih skor maksimum pretest. $\mathrm{N}$ gain disebut juga skor ternormalisasi.

$N-$ gain $=\frac{S_{\text {post }}-S_{\text {pre }}}{S_{\text {maks }}-S_{\text {pre }}}$

Peningkatan hasil belajar dapat dilihat dari tingkat perolehan N-gain yang terdapat tiga kategori, yaitu:

Tabel 2. Kategori Tingkat $\mathrm{N}$-gain

\begin{tabular}{lcc}
\hline & Batasan & Kategori \\
\hline$N$-gain $<0,3$ & Rendah \\
$0,3 \leq N$-gain $<0,7$ & Sedang \\
$N$-gain $\geq 0,7$ & Tinggi \\
\hline & (Hake, 1999)
\end{tabular}

Sedangkan statistik inferensial digunakan untuk menguji hipotesis penelitian. Sebelum melakukan uji hipotesis, terlebih dahulu dilakukan uji prasyarat analisis berupa uji normalitas dengan chi-kuadrat dan uji homogenitas dengan uji Fisher. Data dalam penelitian ini dianalisis dengan bantuan Microsoft Excel 2013. Uji normalitas dilakukan untuk mengetahui populasi yang dipakai berdistribusi normal atau tidak. Pengujian normalitas digunakan rumus Chi-Kuadrat, yaitu:

$\chi 2=\sum_{t=1}^{k} \frac{\left(\mathrm{O}_{\mathrm{i}}-\mathrm{E}_{\mathrm{i}}\right)^{2}}{\mathrm{E}_{1}}$

(Sudjana, 2005)

Uji homogenitas digunakan untuk menunjukkan bahwa kelas-kelas dalam populasi memiliki homogenitas yang sama. Rumus yang digunakan adalah uji Fisher, yaitu:

$\mathrm{F}=\frac{\text { Varians terbesar }}{\text { Varians terkecil }}$

(Sugiyono, 2016) 
Pengujian hipotesis yang digunakan adalah uji-t dengan menggunakan persamaan:

$$
t=\frac{\overline{X_{1}}-\overline{X_{2}}}{S \sqrt{\frac{1}{n 1}+\frac{1}{n 2}}}
$$

(Tiro, 2015)

\section{HASIL DAN PEMBAHASAN}

1. Hasil

\section{a. Analisis Deskriptif}

Hasil analisis statistik deskriptif menunjukkan deskripsi tentang karakteristik distribusi nilai tes hasil belajar dari masing-masing kelompok penelitian.

Tabel 3. Hasil Analisis Statistik Deskriptif Data Hasil Belajar Kelas Eksperimen dan Kelas Kontrol

\begin{tabular}{clcccc}
\hline \multirow{2}{*}{ No. } & \multicolumn{2}{c}{ Statistik } & \multicolumn{2}{c}{ Kelas Eksperimen } & \multicolumn{2}{c}{ Kelas Kontrol } \\
\cline { 3 - 5 } & & Pretest & Posttest & Pretest & Posttest \\
\hline 1. & Jumlah Sampel & 26 & 26 & 25 & 25 \\
2. & Skor Tertinggi & 30 & 53 & 29 & 41 \\
3. & Skor Terendah & 9 & 23 & 6 & 15 \\
4. & Skor Rata-rata & 18,81 & 42,57 & 16,6 & 28,48 \\
5. & Std. Deviasi & 6,45 & 7,49 & 5,24 & 5,90 \\
6. & Varians & 41,60 & 56,16 & 27,49 & 34,91 \\
\hline
\end{tabular}

Berdasarkan Tabel 3 diperoleh bahwa nilai hasil belajar IPA pada materi sistem pencernaan manusia kelas eksperimen yang diajar menggunakan model pembelajaran kooperatif tipe make a match dan kelas kontrol yang diajarkan dengan pembelajaran konvensional terdapat perbedaan.

Pemahaman peserta didik pada materi sistem pencernaan manusia pada kelas eksperimen dan kelas kontrol dapat dilihat dari persentase pencapaian tiap indikatornya. Ada 13 indikator yang harus dicapai peserta didik dalam materi sistem pencernaan manusia, yaitu pada indikator 1 diwakili oleh 3 soal, indikator 2 diwakili oleh 1 soal, indikator 3 diwakili oleh 2 soal, indikator 4 diwakili oleh 1 soal, indikator 5 diwakili oleh 1 soal, indikator 6 diwakili 1 soal, indikator 7 diwakili 2 soal, indikator 8 diwakili oleh 2 soal, indikator 9 diwakili oleh 2 soal, indikator 10 diwakili oleh 1 soal, indikator 11 diwakili oleh 3 soal, indikator 12 diwakili oleh 4 soal, dan indikator 13 diwakili oleh 2 soal. Jenjang kemampuan kognitif yang dipakai yaitu C1 (mengingat), C2 (memahami), C3 (menerapkan), dan C4 (menganalisis). Persentase pencapaian tiap indikator kelas eksperimen dan kelas kontrol dapat dilihat pada Tabel 5

Tabel 5 Persentase Pencapaian Indikator Posttest Hasil Belajar Peserta Didik

\begin{tabular}{clccc}
\hline No & \multicolumn{1}{c}{ Indikator } & No. soal & $\begin{array}{c}\text { Persentase pencapaian } \\
\text { Eksperimen\% }\end{array}$ & Kontrol\% \\
\hline \multicolumn{1}{c}{$\begin{array}{l}\text { Menganalisis jenis-jenis bahan makanan serta } \\
\text { kandungan bahan makanan dalam kehidupan sehari- } \\
\text { hari melalui uji bahan makanan }\end{array}$} & $5,6,3$ & $79,49 \%$ & $38,67 \%$ \\
2 & $\begin{array}{l}\text { Menganalisis sumber energy yang terdapat dalam } \\
\text { bahan makanan }\end{array}$ & 1 & $84,62 \%$ & $92,00 \%$ \\
3 & $\begin{array}{l}\text { Menjelaskan indicator positif dari uji bahan makanan. } \\
\text { Menyebutkan jenis-jenis bahan makanan serta } \\
\text { kandungan bahan makanan yang mengandung } \\
\text { vitamin. }\end{array}$ & 7,4 & $73,08 \%$ & $56,00 \%$ \\
\hline
\end{tabular}




\begin{tabular}{|c|c|c|c|c|}
\hline \multirow{2}{*}{ No } & \multirow{2}{*}{ Indikator } & \multirow{2}{*}{ No. soal } & \multicolumn{2}{|c|}{ Persentase pencapaian } \\
\hline & & & Eksperimen\% & Kontrol\% \\
\hline 5 & $\begin{array}{l}\text { Menyebutkan berbagai mineral yang dibutuhkan oleh } \\
\text { tubuh manusia }\end{array}$ & 8 & $96,15 \%$ & $48,00 \%$ \\
\hline 6 & Menyebutkan fungsi air bagi tubuh manusia & 9 & $100 \%$ & $96,00 \%$ \\
\hline 7 & $\begin{array}{l}\text { Menuliskankan organ-organ utama dalam sistem } \\
\text { pencernaan manusia }\end{array}$ & 10,13 & $96,15 \%$ & $86,00 \%$ \\
\hline 8 & $\begin{array}{l}\text { Menganalisis organ-organ utama dalam sistem } \\
\text { pencernaan manusia }\end{array}$ & 14,15 & $55,85 \%$ & $56,00 \%$ \\
\hline 9 & $\begin{array}{l}\text { Menjelaskan proses pencernaan mekanis dan kimiawi } \\
\text { dalam tubuh manusia }\end{array}$ & 11,12 & $86,54 \%$ & $74,00 \%$ \\
\hline 10 & $\begin{array}{l}\text { Menuliskan organ-organ pencernaan tambahan dalam } \\
\text { sistem pencernaan manusia }\end{array}$ & 16 & $53,85 \%$ & $24,00 \%$ \\
\hline 11 & $\begin{array}{l}\text { Menganalisis organ-organ pencernaan tambahan } \\
\text { dalam sistem pencernaan manusia }\end{array}$ & $17,18,19$ & $67,95 \%$ & $34,64 \%$ \\
\hline 12 & $\begin{array}{l}\text { Menuliskan gangguan pada organ-organ pencernaan } \\
\text { manusia }\end{array}$ & $\begin{array}{l}21,23,24 \\
22\end{array}$ & $75 \%$ & $58,00 \%$ \\
\hline 13 & $\begin{array}{l}\text { Menganalisis gangguan pada organ-organ pencernaan } \\
\text { manusia }\end{array}$ & 25,20 & $84,62 \%$ & $56,00 \%$ \\
\hline & Rata-rata & & $79,247 \%$ & $63,026 \%$ \\
\hline
\end{tabular}

Peningkatan hasil belajar IPA tiap indikator kelas eksperimen (Model pembelajaran kooperatif tipe make a match) dan kelas kontrol yang diajarkan dengan pembelajaran konvensional dapat dilihat dari diagram batang di bawah ini.

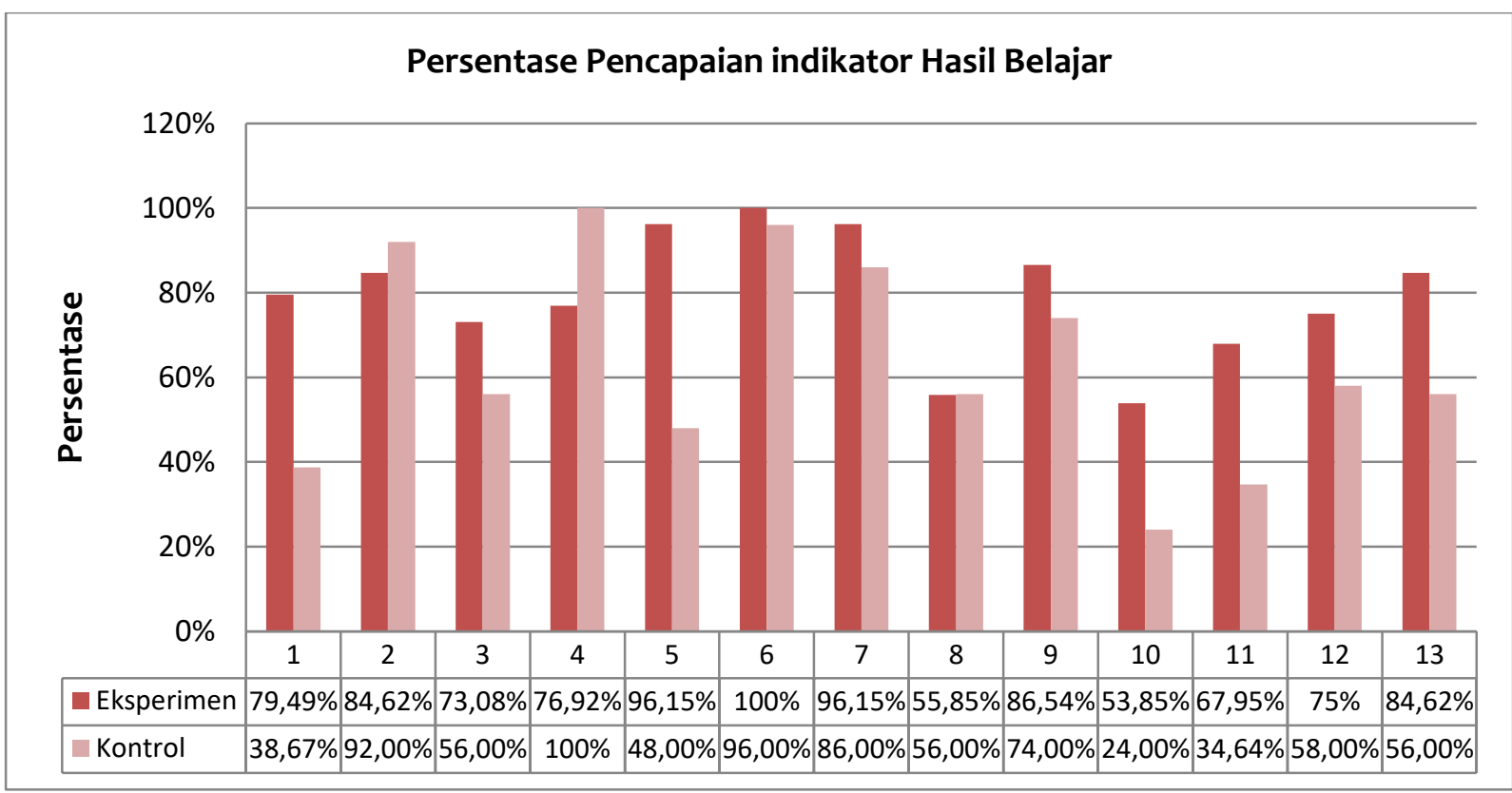

Gambar 1. Diagram Persentase Pencapaian Hasil Belajar IPA Tiap Indikator

Pengumpulan data hasil penelitian dilakukan menggunakan alat pengumpulan data berupa tes pilihan ganda. Untuk mengetahui hasil penelitian yang dilakukan, maka perlu diadakan perbandingan hasil prestest dengan posttest dari kedua kelompok, serta membandingkan normal gain dari kedua kelompok tersebut. 
Setelah diperoleh skor pretest dan posttest dari kedua kelas penelitian, dilakukan analisis $\mathrm{N}$ Gain untuk mengetahui peningkatan hasil belajar IPA peserta didik. Hasil analisis N-Gain seperti pada Tabel 8.

Tabel 8 Rata-Rata N-Gain Tes Hasil Belajar Kelas Kontrol dan Kelas Eksperimen

\begin{tabular}{lcc}
\multicolumn{1}{c}{ Kelas } & Rata-Rata Skor N-Gain & Kategori \\
\hline $\begin{array}{l}\text { Kelas Eksperimen } \\
\text { Kelas Kontrol }\end{array}$ & 0,701 & Tinggi \\
\hline
\end{tabular}

Tabel 8 menunjukkan bahwa hasil belajar peserta didik pada kelas eksperimen yang diajar menggunakan model kooperatif tipe make a match memiliki skor N-Gain 0,701 dengan kategori tinggi, sedangkan hasil belajar peserta didik pada kelas kontrol yang diajar menggunakan pembelajaran konvensional memiliki skor $\mathrm{N}$-Gain 0,318 dengan kategori sedang.

\section{b. Analisis Inferensial.}

Kelas eksperimen, dari hasil perhitungan tabel diperoleh nilai $X^{2}$ hitung sebesar 10,565061 sedangkan nilai $X^{2}$ tabel pada taraf signifikan $a=0,05$ dan derajat kebebasan $(\mathrm{dk})=\mathrm{n}-1$ diperoleh $X^{2}$ tabel $=11,07050$. Berdasarkan hasil analisis data tersebut dinyatakan bahwa $X^{2}$ hitung $<X^{2}$ tabel yaitu $10,565061<11,07048$ maka dapat disimpulkan data pada kelas eksperimen (posttest) terdistribusi normal. Kelas kontrol, dari hasil perhitungan tabel diperoleh nilai $X^{2}$ hitung sebesar 7,29059 sedangkan nilai $X^{2}$ tabel pada taraf signifikan $a=0,05$ dan derajat kebebasan $(\mathrm{dk})=\mathrm{n}-1$ diperoleh $X_{\text {tabel }}^{2}=11,07050$. Berdasarkan hasil analisis data tersebut dinyatakan bahwa $X^{2}$ hitung $<X^{2}$ tabel yaitu $7,29059<11,0704$ maka dapat disimpulkan data pada kelas kontrol (posttest) terdistribusi normal.

Setelah kedua sampel dinyatakan terdistribusi normal, maka dilakukan uji homogenitas. Berdasarkan hasil perhitungan untuk data dari kelas eksperimen dan kontrol diperoleh $\mathrm{F}_{\text {hitung }}=$ 1,86945542, pada taraf nyata $\alpha=0,05$, maka $F_{\text {tabel }}=1,9749594$. Oleh karena itu $F_{\text {hitung }}=1,86945542<$ $F_{\text {tabel }}=1,9749594$. Sedangkan pada pengujian homogenitas data pretest pada kelas eksperimen dan kelas kontrol diperoleh $F_{\text {hitung }}=0,98601399$. Pada taraf nyata $\alpha=0,05$, maka $F_{\text {tabel }}=1,9749594$. Oleh karena itu $F_{\text {hitung }}=0,98601399<F_{\text {tabel }}=1,9749594$, hal ini menunjukan data nilai hasil belajar yang dicapai kelas eksperimen dan kelas kontrol mempunyai varians yang homongen.

Berdasarkan pengujian hipotesis dengan menggunakan uji-t hasil analisis diperoleh $t_{\text {hitung }}=$ 49,612 $>t_{\text {tabel }}=2,01 \mathrm{Hal}$ ini berarti $H_{0}$ ditolak dan $H_{1}$ diterima. Sehingga dapat disimpulkan bahwa terdapat perbedaan antara hasil belajar IPA peserta didik kelas VIII SMP Negeri 31 Bulukumba yang dibelajarkan dengan model pembelajaran kooperatif tipe make a match dan peserta didik yang dibelajarkan dengan menggunakan model pembelajaran konvensional.

\section{Pembahasan}

Berdasarkan pretest hasil belajar yang diperoleh dapat dilihat bahwa pada kelas eksperimen, diperoleh skor rata-rata peserta didik 18,81 sedangkan pada kelas kontrol yaitu 16,6. Kemudian dapat kita lihat bahwa skor rata-rata posttest yang diperoleh pada kelas eksperimen yaitu 42,577 dan pada kelas kontrol yaitu 28,48. Dalam hal ini, terjadi peningkatan hasil belajar peserta didik sebelum dan setelah dilakukan pembelajaran menggunakan model kooperatif tipe make a match dan menggunakan model pembelajaran konvesional. Menurut (Wardani, Faudy, \& Andayani, 2016), model pembelajaran make a match adalah model pembelajaran yang didesain seperti permainan kartu yang berisi soal dan jawaban materi yang sedang dipelajari. Semakin seringnya peserta didik menyelesaikan soal dalam model ini akan membuat mereka lebih memahami materi karena terbiasa 
memecahkan soal-soal serupa. Hasil belajar peserta didik yang diukur pada penelitian ini hanya pada aspek kognitif. Peserta didik tergolong aktif itu ketika memperhatikan pendidik, bekerjasama aktif mengemukakan pendapat jadi materi yang diterima oleh peserta didik dapat dipahami dan diingat dengan baik kemudian saat diberikan tes, peserta didik dapat menjawab soal dengan mengingat dari apa yang mereka pelajari. Sesuai dengan hasil penelitian Saregar, Latifah, \& Sari (2016) mengatakan adanya pemahaman konsep merupakan kesanggupan memahami setingkat lebih tinggi dari pada mengingat, berarti materi yang sudah didapat tidak mudah dilupakan begitu saja.

Pencapaian indikator yang paling tinggi pada kelas eksperimen adalah indikator 6 yaitu 100\%, Menyebutkan fungsi air bagi tubuh manusia. Sedangkan pada kelas kontrol indikator paling tinggi adalah indikator 4 yaitu 100\%, Menyebutkan jenis-jenis bahan makanan serta kandungan bahan makanan yang mengandung vitamin. Adapun soal pada indikator ini merupakan jenis soal yang tergolong mudah untuk diingat sehingga kemampuan peserta didik untuk menjawab soal pada indikator ini juga lebih mudah. Berdasarkan hasil pembelajaran yang telah dilakukan menggunakan pembelajaran kooperatif tipe make a match, sebagian besar peserta didik sudah memahami materi yang berkaitan dengan indikator tersebut, Sedangkan pada kelas kontrol model pembelajaran yang diterapkan tidak menggunakan model pembelajaran kooperatif tipe make a match dimana pada saat proses pembelajaran pendidik yang menjelaskan dari awal hingga akhir pelajaran atau dengan kata lain pendidik lebih dominan ceramah jadi kemungkinan peserta didik agak bosan.

Hasil analisis $\mathrm{N}$-gain ditemukan bahwa rata-rata penskoran hasil belajar peserta didik pada kelas eksperimen diperoleh skor rata-rata 0,701 termasuk kategori tinggi dan pada kelas kontrol diperoleh skor rata-rata 0,318 termasuk kategori sedang. Dengan menggunakan model pembelajaran kooperatif tipe make a match dilihat dari pelaksanaannya model pembelajaran make a match membuat peserta didik bekerja dalam tim dan semua peserta didik harus menguasai pelajaran tersebut, sehingga peserta didik dituntut aktif. Apabila peserta didik menguasai pelajaran, maka hasil belajar juga akan meningkat. Kelas eksperimen yang diajar menggunakan model pembelajaran kooperatif tipe make a match lebih tinggi dibandingkan kelas kontrol yang tidak diajar menggunakan model pembelajaran kooperatif tipe make a match. Menurut (Fitriani \& Hadi, 2014), pembelajaran kooperatif tipe make a match lebih efektif dalam meningkatkan hasil belajar peserta didik. Hal ini disebabkan karena kerjasama antar peserta didik terjalin dengan lancar, pendidik maupun peserta didik sudah bisa menjalankan fungsi dan perannya dalam metode pembelajaran make a match dengan baik serta dapat meningkatkan keaktifan belajar peserta didik.

Memperkuat hasil analisis deskriptif, maka dilakukan analisis statistik inferensial untuk membuktikan hipotesis yang diajukan dengan menggunakan statistik uji-t. Sebelum digunakan ujit, terlebih dahulu dilakukan uji normalitas dan homogenitas dan diperoleh data untuk kelas eksperimen dan kontrol terdistribusi normal juga homogen. Hasil analisis inferensial dengan menggunakan uji-t diperoleh diperoleh $t_{\text {hitung }}=49,612>t_{\text {tabel }}=2,01$. Hal ini berarti $H_{0}$ ditolak dan $H_{1}$ diterima. Sehingga dapat disimpulkan bahwa terdapat perbedaan peningkatan hasil belajar IPA peserta didik kelas VIII SMP Negeri 31 Bulukumba yang dibelajarkan dengan menggunakan model pembelajaran kooperatif tipe make a match pada materi sistem pencernaan manusia.

Sejalan dengan penelitian yang dilakukan oleh (Fitriani \& Hadi, 2014), Uji homogenitas berdasarkan pengolahan dengan alat bantu Microsoft Excel diperoleh $F_{\text {hitung }}=1,14$ dan $F_{\text {tabel }}=1,76$. Karena $\mathrm{F}_{\text {hitung }}<\mathrm{F}_{\text {tabel }}$ maka $\mathrm{H}_{\mathrm{o}}$ diterima dan $\mathrm{H}_{1}$ ditolak dan dapat disimpulkan kedua varians kelas tersebut homogeny. Uji hipotesis menunjukkan diperoleh $t_{\text {hitung }}=6,63$ dan diperoleh $t_{\text {tabel }}=2,00$. Karena $\mathrm{t}_{\text {tabel }}<\mathrm{t}_{\text {hitung }}$ maka $\mathrm{H}_{\mathrm{o}}$ ditolak dan $\mathrm{H}_{1}$ diterima. Jadi rata-rata hasil belajar siswa yang mendapat pembelajaran Make a Match lebih baik daripada rata-rata hasil belajar siswa yang mendapat pembelajaran dengan metode ceramah. 


\section{KESIMPULAN}

Berdasarkan hasil analisis data dan pembahasan maka dapat disimpulkan bahwa:

1. Rata-rata peningkatan hasil belajar IPA peserta didik kelas VIII SMP Negeri 31 Bulukumba, yang diajar dengan menggunakan model pembelajaran kooperatif tipe Make a Match dengan skor $\mathrm{N}$-Gain sebesar 0,701.

2. Rata-rata peningkatan hasil belajar IPA peserta didik kelas VIII SMP Negeri 31 Bulukumba, yang diajar dengan menggunakan pembelajaran konvensional dengan skor $\mathrm{N}$-Gain sebesar 0,318 .

3. Terdapat perbedaan hasil belajar peserta didik kelas VIII SMP Negeri 31 Bulukumba yang dibelajarkan menggunakan model pembelajaran kooperatif tipe Make a Match dengan peserta didik yang dibelajarkan dengan menggunakan model pembelajaran konvensional

\section{DAFTAR PUSTAKA}

Arifin, Z. (2016). Evaluasi Pembelajaran. Bandung: Remaja Rosdakarya.

Fatimatuzzahro, Subiki, \& Wahyuni, S. (2015). Penerapan Model Cooperative Learning dengan Teknik Make A Match Terhadap Keterampilan Proses Sains dan Hasil Belajar Siswa pada Pembelajaran IPA di SMP . Jurnal Pendidikan Fisika, Vol. 4 No.2,, 150.

Fitriani, E., \& Hadi, S. (2014). Keefektifan Metode Pembelajaran Make A Match Terhadap Hasil Belajar Kompetensi Dasar Permintaan dan Penawaran Uang pada Siswa Kelas X SMA Negeri 16 Semarang. Economic Education ANalysis Journal, 66.

Hake, R. R. (1999). Analyzing Change, Gain Score. Http://www.physich.indiana.edu/.

Iwan, \& Lestari, N. P. (2015). Penerapan Model Pembelajaran Kooperatif Tipe Make A Match untuk Meningkatkan Motivasi dan Hasil Belajar Biologi pada Materi Ekosistem. Jurnal Nalar Pendidikan Volume 3, Nomor 2,, 80-81.

Kurniasih, I., \& Sani, B. (2017). Ragam Pengembangan Model Pembelajaran untuk Meningkatkan Profesionalitas Guru. Jakarta: Kata Pena.

Mikran, Pasaribu, M., \& Darmadi, I. W. (2013). Penerapan Model Pembelajaran Kooperatif Make A Match untuk Meningkatkan Hasil Belajar Siswa Kelas VIIA SMP Negeri 1 Tomini Pada Konsep Gerak . Jurnal Pendidikan Fisika Tadulako (JPFT) Vol. 2 No. 2 , 11.

Permendikbud. (2014). Penilaian Hasil Belajar oleh Pendidik pada Pendidikan Menengah. Jakarta: Menteri Pendidikan dan Kebudayaan Republik Indonesia.

Rusman. (2016). Model-model Pembelajaran: Pengembangan Profesionalisme Guru. Jakarta: PT RajaGrafindo Persada.

Saregar, A., Latifah, S., \& Sari, M. (2016). Efektivitas Model Pembelajaran CUPS: Dampak terhadap Kemampuan Berpikir Tingkat TInggi Peserta DIdik Aliyah Mathla'ul Anwar Gisting Lampung. Jurnal Ilmiah Pendidikan Fisika Al-BiRuNi.

Slavin, R. E. (2009). Cooperative Learning: Teori, Riset dan Praktik. Bandung: Nusa Media.

Sudjana. (2005). Metoda Statistika. Bandung : Tarsito.

Sugiyono. (2016). Metode Penelitian (Pendidikan Pendekatan Kuantitatif, Kualitatif, dan R \& D). Bandung: Alfabeta.

Tiro. (2015). Dasar-Dasar Statistika Edisi Ketiga. Makassar: Andira Publisher.

Wardani, S. R., Faudy, A., \& Andayani, d. (2016). Peningkatan Keaktifan dan Kemampuan Menulis Teks Anekdot dengan Menggunakan Model Pembelajaran Make A Match pada Siswa Kelas X SMK. Jurnal Penelitian Bahasa, Sastra Indonesia dan Pengajarannya, 171. 


\section{Ennar Winarti}

Mahasiswa Program Studi Pendidikan IPA FMIPA UNM, aktif melakukan penelitian pada bidang Pendidikan IPA, dapat dihubungi melalui email:Ennarwinarti26@gmail.com

\section{Muh Tawil}

Dosen Program Studi Pendidikan IPA FMIPA UNM, aktif melakukan penelitian pada bidang Pendidikan IPA, dapat dihubungi melalui email: muh.tawil@unm.ac.id.

\section{Ratnawaty Mamin}

Dosen Program Studi Pendidikan IPA FMIPA UNM, aktif melakukan penelitian pada bidang Pendidikan IPA, dapat dihubungi melalui email: ratnawatymamin1@gmail.com 